\title{
光・電気プリント配線板をべースとした光表面実装技術
}

\author{
三上 修*
}

\section{Optical Surface Mount Technology Based on Opto-Electronic Printed Wiring Board}

Osamu MIKAMI*

$*$ 東海大学工学部通信工学科（† 259-1292 神奈川県平塚市北金目1117）

*Faculty of Engineering, Tokai University (1117 Kitakaname, Hiratsuka-shi, Kanagawa 259-1292)

\section{1.はじめに}

100兆円を越える市場規模が予測されているマルチメデ イア時代には, 情報ニーズの高度化・多様化, デジタル化 が進み，ネットワークを介して流通する情報量は現在とは 比較にならないほど増大すると予測されている。この膨大 な情報を円滑に伝送・処理するためには，通信装置やコン ピュータの処理能力を飛躍的に向上させる必要がある。情 報量の飛躍的拡大に対処する手段として，銅線ケーブルに 比して数万倍の情報伝送容量の光ファイバを中心とする光 エレクトロニクス技術への期待が大きい。

現在の光エレクトロニクス技術を眺めると, 半導体レー ザや光検出器といった個々のデバイスの性能向上に関する 研究開発面では着実に進歩してきた。しかし配線上, 寸法 上, 信号の伝わり方等でエレクトロニクス（電気）とは異 なる「光の特殊性」のため，集積化や実装技術面で深刻な 課題にぶつかっている。これらについては，本講座「絵解
き・光実装技術入門」において，詳しく述べられてきた。 では，近未来の光実装はどういう姿になっているだろう か？ 本稿では光実装技術の階層のなかで特にボードレベ ルの実装がもつ課題に対して,一つの有望な解決策として, 著者らが検討している光・電気 (OE) プリント配線板を ベースとした光表面実装技術（光SMT：Optical Surface Mount Technology) ${ }^{1)-31}$ について紹介する。

\section{2. 階層別の光実装技術}

図 1 に示した光エレクトロニクス実装の階層構成を参考 にして，階層別の光実装技術をざっと眺めてみよう。まず LSIチップ内での信号接続の危機が指摘されている。LSI の超高速化, 高密度化の進展とともにチップ内部における 信号接続に遅れと減衰が生じる。LSI上の金属配線抵抗は 微細化とともに上昇し, かつ増大する配線容量とともに大 きなRC時定数となり，信号の遅れは著しくなる。この第 1 階層のチップレベルに, 光接続の導入が検討されている。

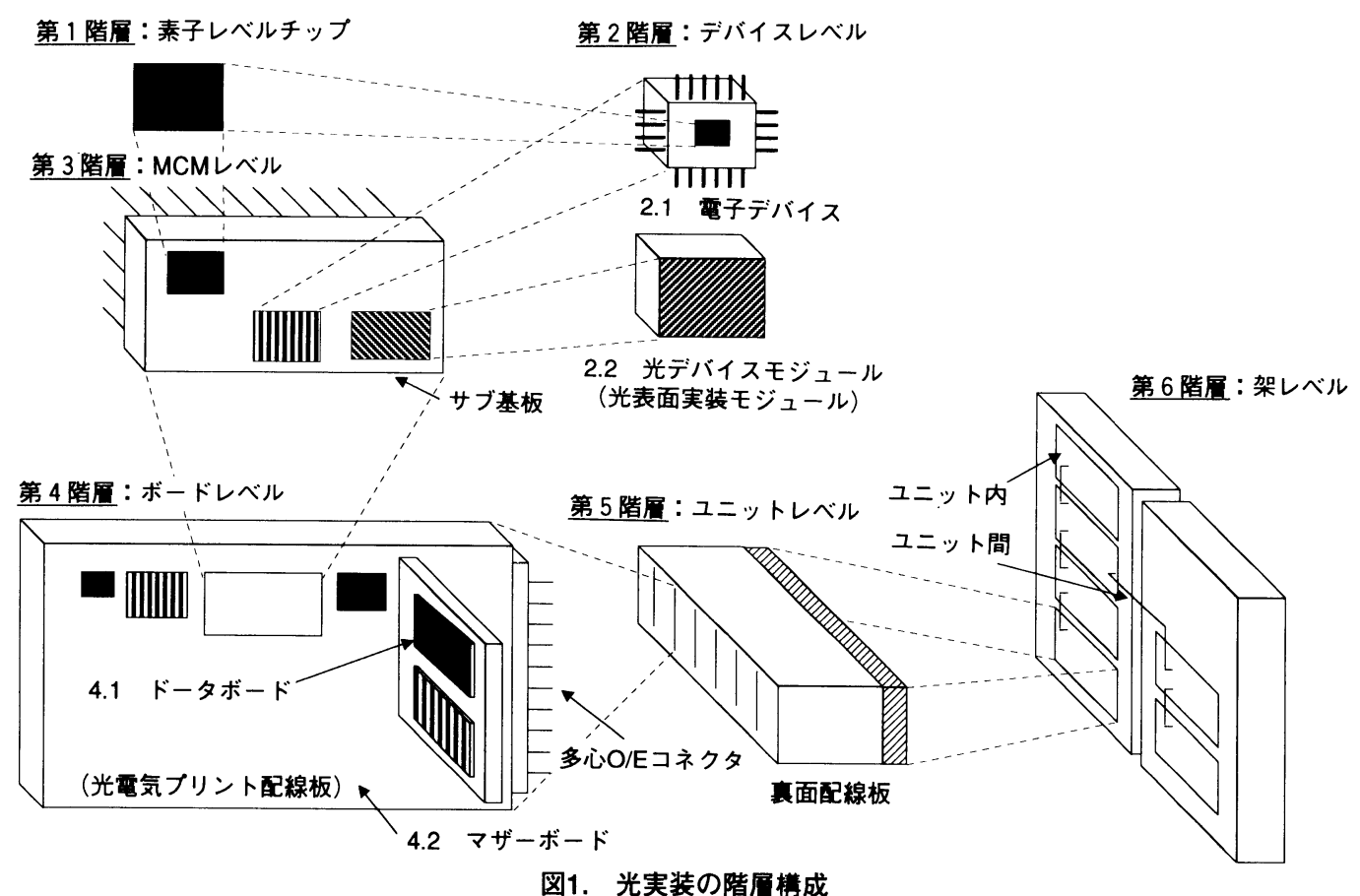


第 2 階層のデバイスレベルでは，共通の基板上に複数の 光素子をアライメントフリーで設置する構成が研究されて いる。例えばPLC（石英系プレーナ光波回路）を基盤（プ ラットフォーム) として, 半導体レーザやフォトダイオー ド等を直接搭載するハイブリッド光集積技術への関心が高 まっている。従来は結合レンズ等を介して, 空間的に光結 合するものが実用的に多用されていた。この場合, 光固有 の位置合わせ困難さのため, アライメントに要する労力は きわめて大きく，コスト増大の主因であった。半導体レー ザ構造に新たな工夫を加えて, レーザ光のスポットサイズ を変換する機構を付加し, 光固有のアライメントの困難さ をできるだけ軽減して，レンズ不要で光ファイバや光導波 路と直接結合する研究が進展した成果である。

コンピュータや交換機などでは，セラミック基板上に多 数のLSIチップが並べられている。これらのチップ間を光 導波路で結ぶ方式が，第 3 階層の光技術として検討されて いる。銅ポリイミド配線板をベースに, フッ素化ポリイミ ド光導波路を積層一体化した光・電気混載配線板を用い, 半導体レーザフォトダイオードとLSIをマルチチップモジ ユール（MCM）実装した例がある。高速デー夕通信や高 精度画像通信等を含む将来のマルチメディアサービスの実 現には, 広帯域性・高密度性などの特徴を有する光導波路 インタコネクションを融合させた電気・光混載型MCMが 有力と考えられている。

第 4 階層のボード上には現在, 図 2 に示すようなファイ バピッグテール方式（ファイバを接続した構造）の光デバ イス/モジュール等を実装することが主流となっている。 光技術がアクセス系, 光交換, 光情報处理に進むにつれて, ボード上に搭載される光デバイス/モジュールの数が増加 すると予測される。この結果, 個々のデバイス/モジュー ルに接続されているファイバの余長でボード上は埋め尽く され, 取り扱い性, 寸法, 故障率, 経済性などの点から, 深刻な問題になる。それにもかかわらず，この第 4 階層 （第 3 階層の一部を含む）のカード/ボード上への光デバ イス実装が従来ほとんど研究されていなかった。その意味 で，著者らは光表面実装技術（光SMT）を提案し検討を 進めてきた。光表面実装技術については後の節で詳述する。

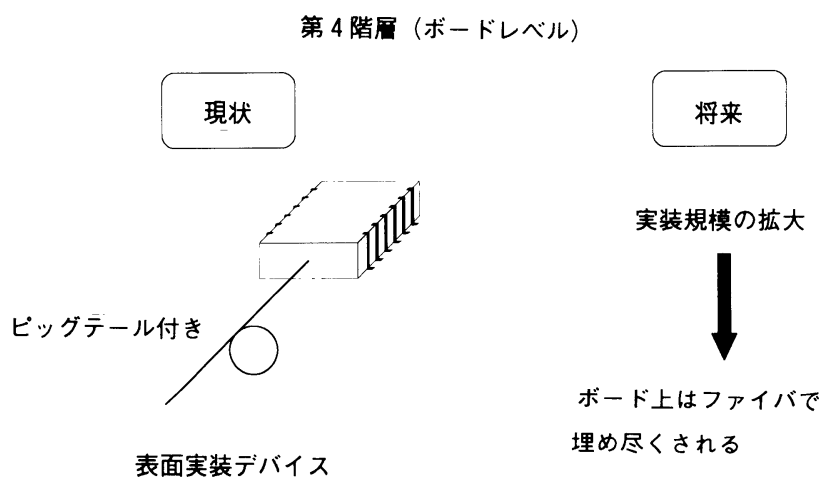

図2. 第 4 陼層の問題
最もニーズが顕在化しており，かつ経済的にも電気イン タコネクションを凌駕しうると考えられているのが，第 5 階層と第 6 階層での光インタコネクションである。ボード のスループットが増大するにつれて信号配線がシステム性 能向上のボトルネックになりつつある。また接続本数の増 加に伴い内部でのケーブル敷設が困難になり，ケーブルか ら放射される電磁ノイズも問題となる。これらの解消のた め注目されているのが光インタコネクションである。コン ピュータや交換機等のユニット間の接続で大量に使用され ている同軸ケーブル束を多心光ファイバで置き換え，高 速・高密度配線を軽量・細径で実現することを狙ってい る。

\section{3. 光・電気 $(\mathrm{OE})$ プリント配線板}

一昔前のラジオを分解すると, アルミでできた「シャー シ」と呼ばれるケース内部では，たばこサイズの電気抵抗 やコンデンサがはんだと銅線を使い，空中配線で接続され ていた。真空管からトランジス夕の時代まで同じ実装技術 が使われてきた。しかし現在では，多くのパソコンや電気 計測器の中では, プリント配線板とよばれる厚さ1-2mmの 樹脂基板に銅線代わりの銅板回路が焼き付けられ，そこに 超小型の電気部品やLSIが表面実装されている。表面実装 とは, プリント配線板の表面に形成された線路に，ロボッ トなどによって自動的に位置合わせされた電気部品をはん だのリフローによって接続固定することを可能にした技術 である。エレクトロニクス（電気）実装に関わっておられ る読者はこの技術に詳しいと思う。

さて電気信号を伝える銅線に加えて，光信号を伝える光 導波路を共通の基板上に形成したものが，光・電気 (OE) プリント配線板とよばれるものである。先に述べた光・電 気 $(\mathrm{OE})$ 混載配線板がひとつの例である。将来, 光エレ クトロニクス実装技術が進展すれば，プリント配線板の大 半はOEプリント配線板になるだろう。この意味で，プリ ント配線板を生産されている企業も光実装技術が何かを習 得される必要が生じると思われる。

\section{4. 光表面実装技術（光SMT）の基本概念}

それでは本論の光表面実装技術（光SMT）について説 明しょう。これは, 電子回路の表面実装技術（SMT）に 対応するボードレベルでの新しい光実装技術である。今後 の光エレクトロニクスの量的拡大に対応するためには, 生 産現場での調整や組み立てに要する工数を削隇し, さらに 様々なニーズに即応する設計や個別部品の事前検查が可能 でなければならない。このようなことを考慮した場合に， 光SMTは以下の基本条件を具備する必要があろう。

(1) 光デバイスと電子回路を組み込んだOEデバイスと, 光導波路と電気配線で構成されたOEプリント配線板 を主要構成部品とする。 
(2) $\mathrm{OE}$ デバイスを光・電気プリント配線板に挿入・固 定するだけで，光および電気接続が行われて，かつ調 整工数を必要としない構造とする。

(3) 光・電気プリント配線板は光導波路および電気配 線を同一基板上に有し，基板の主要材料は非結晶材料 で経済的なものが望ましい。

上記の基本条件を満たした光SMTの基本概念図を図 3 (a)に示す。光・電気デバイスの底面には位置決め用のガ イドピンが付いており，これをOEプリント配線板のかん ごう孔に差し込むだけでOEデバイスの光入出力端子およ

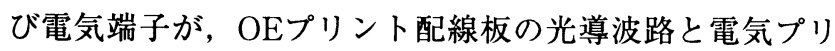
ント配線にそれぞれ結合される。図3(b)に断面構造を示す。 電気配線は従来と同じく基板表面に作成され, 光導波路は キズや污れ防止のため基板表面より内側に作成されている。

光SMT用OEデバイスパッケージの基本型には, 図 4 に 示すような 2 種類が考えられる。(a)は基板を伝わってき た光がパッケージ内をスルーで通過するタイプである。光 アイソレータ, 外部光変調器, あるいは光増幅器等のデバ イス用である。(b)は光送受信器用のパッケージである。 基板を伝搬してきた光信号はパッケージ内の光検出器で O/E変換され，さらに内蔵された電子回路によって電気的 な処理を行った後に，半導体レーザや発光ダイオードを用 いてE/O変換し光信号が出力される。

OEプリント配線板に要求される条件は, 高性能な光導 波路と電気回路が同一基板に製作可能で, 数十 $\mathrm{cm}$ 程度の 大型基板が経済的に製作可能でなければならない。さらに， 光導波路とOEデバイスを光学的に結合させるためには， 光導波路を伝搬してきた光ビームを，基板表面に垂直な方
向に出射させる光路変換の構造を有していなければならな い。これらのことを考慮すると，OEプリント配線板の構 成方法として次のような候補が考えられる。

(1) 半導体（シリコン）基板上に形成された石英の光 導波路

(2) 多成分ガラス光導波路

(3) 高分子光導波路

上記(1)は低損失な光ファイバ製作技術を平面光導波路 に応用したもので，2.2節で紹介したPLCと呼ばれるもの であり，多種類な光導波回路が製作されている。(2)は, 二重イオン交換法によって, 内部の屈折率が分布をもつ高 性能な光導波路が製作できる。(3)については前述したよ うなポリイミド光導波路による光・電気混載型配線板が注 目される。製作可能なサイズ，量産性や経済性を考慮する と，(3)の高分子系がOEプリント基板の構成方法として有 望だと思われる。

\section{5. 光SMTの試作結果}

OEプリント配線板に微細加工用のマイクロ加工装置に よって45度の切り込みを入れ，基板と空気との屈折率の違 いを利用した全反射面を形成する方法がいくつか検討され

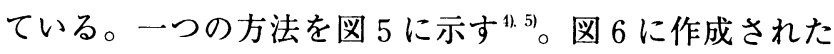
ミラーの断面を示す。45度の先鋭化したエッジ部分に欠け の発生はなく，加工面もまったく傷のない鏡面に近い状態 が実現されている。光が全反射する様子をシミュレーショ ンした結果を図 7 に示す。マルチモード導波路や基板の材 質によっては, 全反射しない光成分も存在することがある。 この分は光パワーの損失となる。平行ビーム型の基本パッ

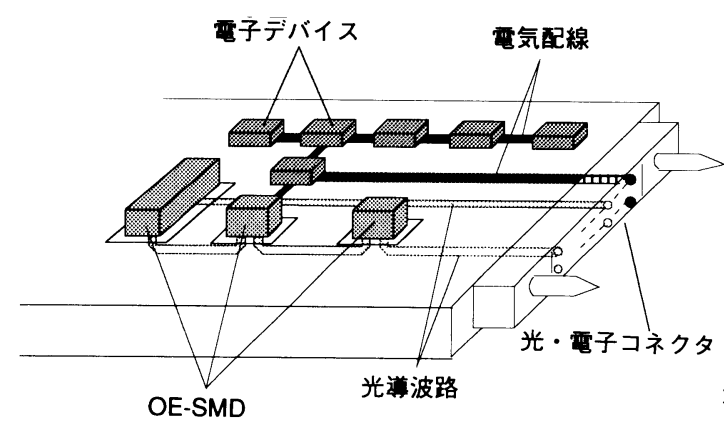

光電子表面実装デバイス

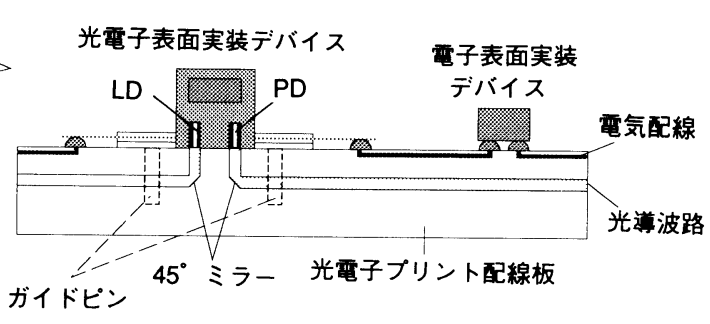

(a)

図3. 光表面実装技術の基本概念(a) と断面樓造(b)

(b)

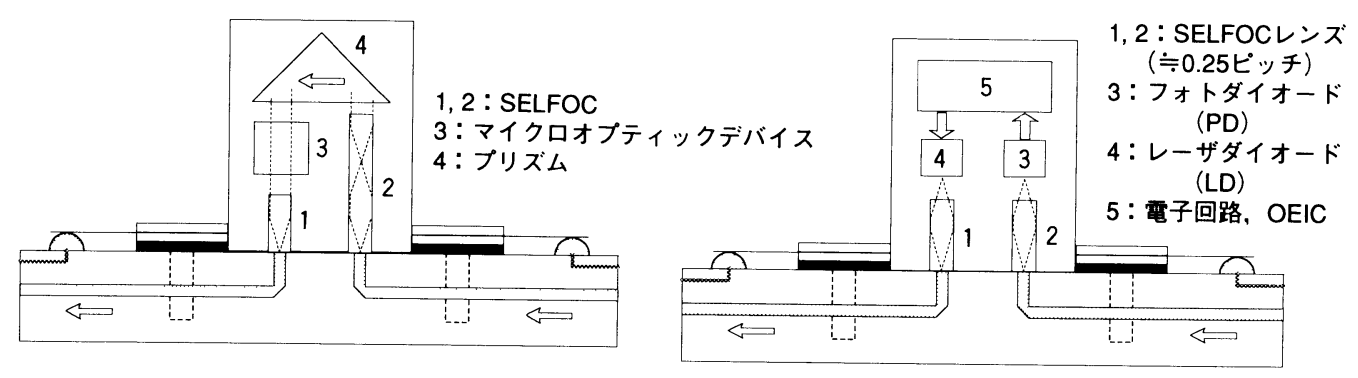

(a)

(b)

図4. 光SMT用OEデバイスパッケージの基本桠造 


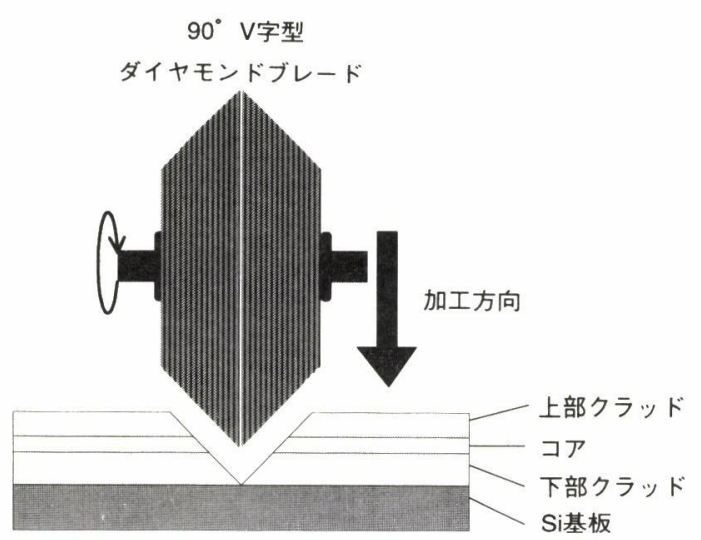

図5. マイクロミラーの作製方法

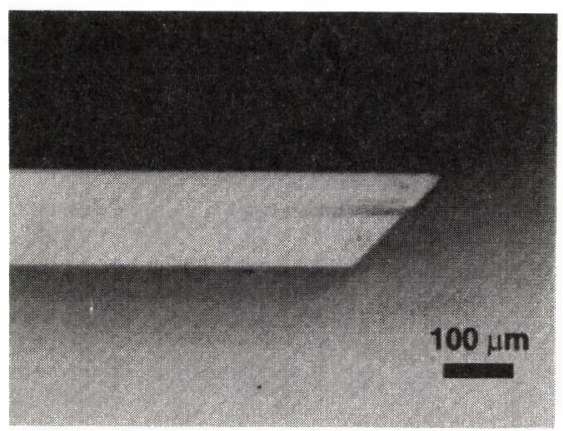

図6. 作製されたマイクロミラーの断面写真

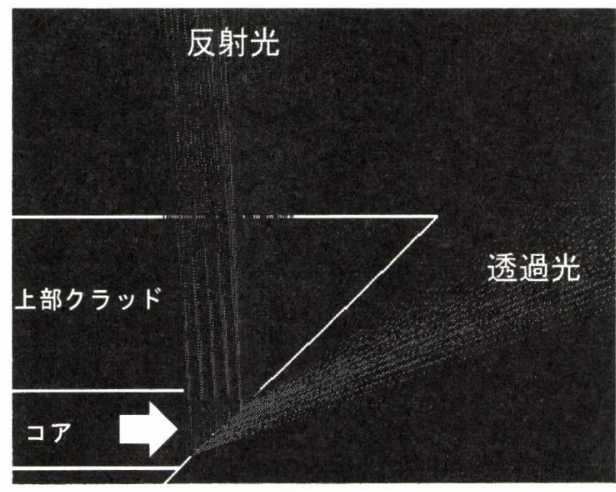

図7．光が全反射する様子

ケージとしては図 8 に示す偏光無依存型の光アイソレータ を組み込んだOEデバイスが試作された。また，図 9 のよ うな半導体レーザおよびフォトダイオードを内蔵した送受 信型光パッケージの試作も試みられている。

\section{6. むすび}

光エレクトロニクス実裝技術を展望するとともに, 新し く提案された光表面実裝技術（光SMT）について紹介し， その実現性を検証するための $2 ， 3$ の試みについて述べた。

最近, 光インタコネクションを含めて光エレクトロニク ス実装技術に関心が寄せられ, エレクトロニクス実装学会, 電子情報通信学会等での主要な研究テーマとして取り上げ られている。光エレクトロニクスの応用範囲の拡大とその 技術の高度化に対応できるよう, 飛躍的革新につながる技 術の開発が求められている。(1998.9.30-受理１998.10.26-再受理)

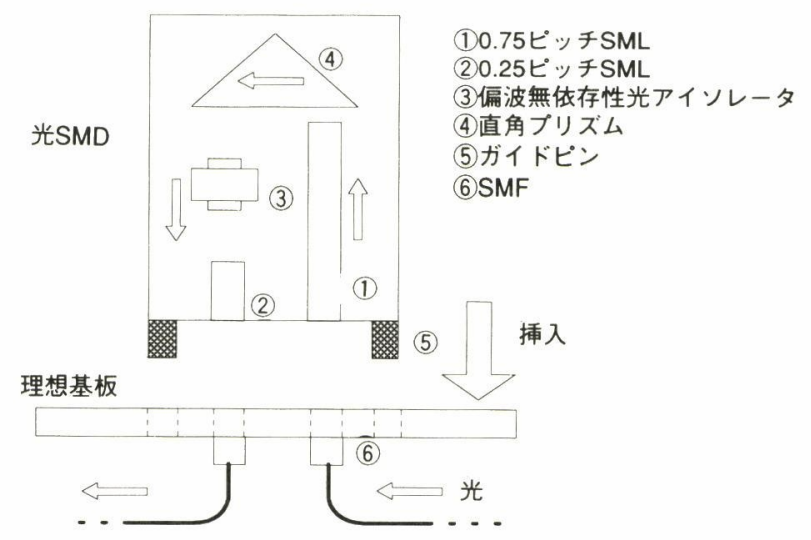

図8. 光アイソレータ內藏OEデパイスの構造

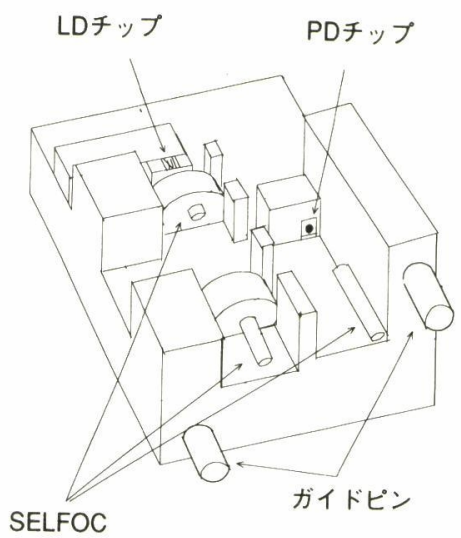

図9. 送受信型OEデパイスのスケッチ

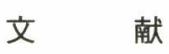

1) T.Uchida, et al. : "Optical surface mount technology", Jpn. J. Appl. Phys., Vol.31, pp.1652-1655, 1992.

2) 内田禎二, 三上 修: “光表面実装技術（光SMT）”, 回路 実装学会誌, Vol.10, No.5, pp.346-350, 1996.

3) T.Uchida and O.Mikami : "Optical Surface Mount Technology", IEICE Trans. on Electronics, Vol.E80-C, No.1, pp.81-87, 1997.

4) 市村 顕, 三上 修, 内田禎二, 吉村了行, 疋田 真: “光 表面実装向け45度ミラー付き高分子導波路”, 回路実装学会 誌, Vol.13, No.2, pp.97-102, 1998.

5) T.Satoh, et al. : "Coupling of Spot-size Converted Laser Diode to Polymeric Waveguide with 45-degree Micro Reflection Mirror for Optical Surface Mount Technology", IEMT/IMC Symposium, pp.114-117, 1998.

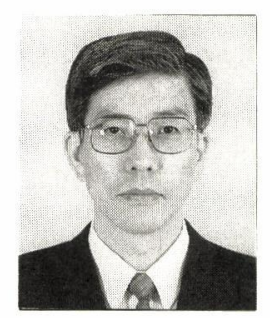

三上 修(みかみ おさむ)

昭和 46 年, 大阪大学大学院修士課程修了。同年, NTT武蔵野電気通信研究所勤務。昭和 60 年 9 月, 英国グラスゴー大学客員研究員。平成 3 年 6 月, 東京大学先端科学技術研究センター寄付 部門客員助教授。平成 6 年 4 月, NTTより東 海大学入移る。現在, 同大学工学部通信工学科 教授。光機能デバイスおよびシステムの研究に 従事。工学博士。 